\title{
Histopathological spectrum of cystic ovarian mass- A one year study
}

\author{
Bharti Devi Thaker ${ }^{1, *}$, Deepa Hans ${ }^{2}$ \\ ${ }^{1}$ Demonstrator, ${ }^{2}$ Lecturer, Dept. of Pathology, GMC Jammu, India \\ *Corresponding Author: \\ Email: bharti68@gmail.com
}

Received: $30^{\text {th }}$ August, 2017

Accepted: $14^{\text {th }}$ November, 2017

\begin{abstract}
Introduction: Ovarian cyst are fluid filled sacs that form within or on the ovary, which can either be non neoplastic or neoplastic. Non neoplastic cyst can be physiologic or pathologic and are more common than neoplastic cyst. This study was undertaken retrospectively for a period of 1 year to determine the histopathological spectrum of ovarian cystic lesions in our hospital.

Result: During the study period 120 cases presenting with ovarian cystic masses were seen. The age range of patient was from 15 to 60 years. Maximum number of cases were seen in the age group of 21-30 years. Non neoplastic cyst were the most common among all the lesion studied of which follicular cyst (53.3\%) made majority of cases. Among the Neoplastic lesion, $83 \%$ were benign tumours followed by malignant tumours (13\%) whereas borderline tumours were found in $3 \%$ only. Serous cystadenoma $(21 \%)$ were the most common benign tumour whereas serous papillary cystadenocarcinoma $(62.5 \%)$ was the most common among the malignant cystic lesion. Most common clinical presentation was abdominopelvic mass (60\%).

Conclusion: Ovarian cystic lesions are commonly encountered surgical specimens. Abdominopelvic mass is the predominant clinical feature. Histopathological examination is important to categorize them into neoplastic and non neoplastic lesion so that proper treatment could be given to the patients.
\end{abstract}

Keywords: Ovarian, Neoplastic, Benign, Malignant.

\section{Introduction}

Ovarian cyst are fluid filled sacs that form within or on the ovary, which can either be non neoplastic or neoplastic. Non neoplastic cyst can be physiologic or pathologic and are more common than neoplastic cyst. ${ }^{1}$ Non neoplastic physiologic cysts are follicular cysts and corpus luteal cyst. $95 \%$ of physiologic ovarian cyst diasappear spontaneously, usually over a course of one or two menstrual cycles. Non neoplastic pathologic cyst involves endometriotic cyst, tuboovarian abcess, cyst of polycystic ovarian syndrome and surface epithelial inclusion cyst. Ovarian epithelial tumours can be benign, borderline or malignant. Benign tumours can be completely cystic (cystadenomas), can have fibrous and cystic areas (cystadenofibromas) or can be predominantly fibrous (adenofibromas). The borderline and malignant tumours that have cystic component are called cystadenocarcinomas. ${ }^{2}$ Distinction between non neoplastic lesion and neoplastic lesion is necessary since proper treatment depends on the histologic abnormality. Hence this study was undertaken to determine the histopathological spectrum of these cystic lesions in our hospital.

\section{Materials and Methods}

It was a 1 year study done retrospectively from May 2016 to April 2017. It was conducted in histopathology section of pathology department of GMC Jammu. Retrospective analysis of all cases with cystic ovarian masses, whose specimens were received in the department, was done. Specimen received were hysterectomy with bilateral/unilateral salphingectomy or oopherectomy. All data, maintained in the histopathology section were retrieved and reviewed. Histology slides of all cases were reviewed. Staining was done by haematoxylin and eosin stain. Each case was analysed with respect to age, clinical presentation and microscopic diagnosis.

\section{Result}

During the study period 120 cases presenting with ovarian cystic masses were seen. Unilateral cases (100 cases) were more than bilateral cases (20 cases). Among the unilateral cases, $60 \%$ occurred on the right side. Among bilateral cases most frequent lesions were follicular cyst and serous cystadenoma: 10 cases and 4 cases respectively. Other bilateral cystic lesion were as follows: mucinous cystadenoma ${ }^{2}$ and Corpus luteal cyst. $^{4}$

The age range of patient was from 15 to 60 years. Maximum number of cases were seen in the age group of 21-30 years followed by 31-40 years age group. Least number of cases were seen in age less than 20 years and above 50 years. Peak age for benign tumours were seen in $3^{\text {rd }}$ to $4^{\text {th }}$ decade whereas peak of malignant tumours were seen in age group of 50 -60 years.

Among 120 ovarian cystic masses seen, non neoplastic cyst were the most common. Among the neoplastic lesion, $83 \%$ were benign tumours followed 
by malignant tumours $(13 \%)$ whereas borderline tumours were found in $3 \%$ only in our study.

Non neoplastic cyst cases were 60 in number. Among non neoplastic lesion $90 \%$ were physiologic and $10 \%$ were pathologic. Follicular cyst was the most common cystic lesion seen in 32 cases. Second most common lesion seen was corpus luteal cyst 22 cases, endometriotic cyst 4 cases, and inclusion cyst 2 cases. Size of non neoplastic cyst ranged from 0.5 to $8 \mathrm{~cm}$.

Out of 120 cases, 50 cases of benign tumour were seen. Serous cystadenoma (25 cases) were the most common. It was followed by mucinous cystadenoma (15 cases), mature cystic teratoma ( 7 cases), cystadenofibroma (2 cases) and granulosa cell tumour (1 case). Size for serous cystadenoma was from $3.5 \mathrm{~cm}$ to $10 \mathrm{~cm}$, for mature cystic teratoma 11 to $20 \mathrm{~cm}$ and for mucinous cystadenoma 11 to $28 \mathrm{~cm}$.

Malignant tumour were seen in 8 cases. Most common were the serous papillary cyst adenocarcinoma (5 cases). It was followed by 3 cases of mucinous cystadenocarcinoma. Size of these tumours ranged from 8 to $20 \mathrm{~cm}$. Borderline tumour were seen in 2 cases both were of Serous papillary borderline tumour.

Most common clinical presentation was abdominopelvic mass $(60 \%)$ followed by pain abdomen $(22 \%)$. Others were bleeding per vaginum (10\%), Incidental finding $(6 \%)$, rupture cyst with hemoperitoneum $(2 \%)$.

Table 1: Histopathological distribution of ovarian cystic lesions

\begin{tabular}{|c|c|c|c|}
\hline Category & Histopathological diagnosis & Number(n) & Percentage (\%) \\
\hline \multirow[t]{4}{*}{ Non Neoplastic lesion $(n=60)$} & Follicular cyst & 32 & $26.6 \%$ \\
\hline & Corpus luteal cyst & 22 & $18.3 \%$ \\
\hline & Endometriotic cyst & 4 & $3.3 \%$ \\
\hline & Inclusion cyst & 2 & $1.6 \%$ \\
\hline \multirow{5}{*}{$\begin{array}{l}\text { Neoplastic }(\mathrm{n}=60) \\
\text { Benign }(\mathrm{n}=50)\end{array}$} & Serous cysadenoma & 25 & $20.8 \%$ \\
\hline & Mucinous Cystadenoma & 15 & $12.5 \%$ \\
\hline & Mature cystic Teratoma & 7 & $5.8 \%$ \\
\hline & Granulosa cell tumour & 1 & $0.8 \%$ \\
\hline & Cystadenofibroma & 2 & $1.6 \%$ \\
\hline \multirow[t]{2}{*}{ Malignant $(n=8)$} & Serous cystadenocarcinoma & 5 & $4.15 \%$ \\
\hline & Mucinous cystadenocarcinoma & 3 & $2.5 \%$ \\
\hline \multirow[t]{2}{*}{ Borderline $(n=2)$} & $\begin{array}{c}\text { Borderline Serous Papillary } \\
\text { tumour }\end{array}$ & 2 & $1.6 \%$ \\
\hline & Total & 120 & 100 \\
\hline
\end{tabular}

Table 2: Age distribution of ovarian cystic lesion

\begin{tabular}{|l|c|c|c|c|}
\hline Age (years) & Non Neoplastic lesion (n) & Benign lesion (n) & $\begin{array}{c}\text { Borderline } \\
\text { lesion(n) }\end{array}$ & $\begin{array}{c}\text { Malignant } \\
\text { Lesion(n) }\end{array}$ \\
\hline $11-20$ & 5 & 2 & - & - \\
\hline $21-30$ & 30 & 18 & - & - \\
\hline $31-40$ & 20 & 23 & 1 & 1 \\
\hline $41-50$ & 3 & 5 & 1 & 2 \\
\hline $51-60$ & 2 & 2 & - & 4 \\
\hline$>60$ & - & - & - & 8 \\
\hline Total & 60 & 50 & 2 & 1 \\
\hline
\end{tabular}

\section{Discussion}

During the study period 120 cases presenting with ovarian cystic masses were seen. Unilateral cases (100 cases) were more than bilateral cases (20 cases). This is similar to study done by kathikar et $\mathrm{al}^{3}$ and Bhuvanesh et al. ${ }^{4}$ Among the unilateral cases, $60 \%$ occurred on the right side. Among bilateral cases most frequent lesions were follicular cyst and serous cystadenoma: 10 cases and 4 cases respectively. Other bilateral cystic lesion were as follows: mucinous cystadenoma (2 cases) and corpus luteal cyst (4 cases).

The age range of patient was from 15 to 60 years. Maximum number of cases were seen in the age group of 21-30 years followed by 31-40 years age group. Least number of cases were seen in age less than 20 years and above 50 years of age. Sheikh $\mathrm{S}$ et $\mathrm{al}^{5}$ in her study found $48.4 \%$ cases in 21-30 years of age group followed by second peak seen in 31-40 years of age group constituting $23.9 \%$ cases similar to that seen in 
our study. Peak age for benign tumours were seen in $3^{\text {rd }}$ to $4^{\text {th }}$ decade. This is similar to study done by Dhakal $\mathrm{R}$ et $\mathrm{al}^{6}$ and Sawant A et al. ${ }^{7}$ Peak of malignant tumours were seen in age group of $50-60$ years. Sawant $\mathrm{A}$ et $\mathrm{al}^{7}$ and Murthy NS et $\mathrm{al}^{8}$ also found maximum number of malignant tumours in patients more than 40 years of age and 55-64 years age group respectively as seen in our study.

Among 120 ovarian cystic masses seen, Non neoplastic cyst were the most common (50\%). Matinez Onsurbe $\mathrm{P}$ et $\mathrm{al}^{9}$ and Kreuzer $\mathrm{GF}$ et $\mathrm{al}^{10}$ reported $41.67 \%$ and $40.39 \%$ of non neoplastic lesion in their study comparable to our study. Among the neoplastic lesion, $83 \%$ were benign tumours followed by malignant tumours (13\%) whereas borderline tumours were found in $3 \%$ only. Sheikh S et $\mathrm{al}^{5}$ in her study had observed $80.3 \%$ benign cases followed by $15.5 \%$ of malignant cases and $4.1 \%$ of borderline cases similar to that seen in our study.

Non neoplastic cyst cases were 60 in number. Among non neoplastic lesion $90 \%$ were physiologic and $10 \%$ were pathologic. Follicular cyst was the most common cystic lesion (32 cases) followed by corpus luteal cyst ( 22 cases). Matinez Onsurbe $\mathrm{P}$ et al ${ }^{9}$ reported $55 \%$ follicular cyst and $45 \%$ corpus luteal cyst in his study. Gupta $\mathrm{N}$ et $\mathrm{al}^{11}$ had observed in his study that follicular cyst and corpus luteal cyst together make $80.2 \%$ of all non neoplastic lesion as seen in our study. Size of non neoplastic cyst ranged from 0.5 to $8 \mathrm{~cm}$.

Out of 120 cases, 50 cases of benign tumour were seen. Serous cystadenoma ( 25 cases) were the most common. This is similar to study done by Gupta $\mathrm{N}$ et al, ${ }^{11}$ Bukhari $\mathrm{U}$ et al ${ }^{12}$ and Momtahen $\mathrm{S}$ et al. ${ }^{13}$ It was followed by Mucinous cystadenoma (15 cases), Mature cystic teratoma (7 cases), cystadenofibroma ( 2 cases) and granulosa cell tumour (1 case). Size for serous cystadenoma was from $3.5 \mathrm{~cm}$ to $10 \mathrm{~cm}$, for mature cystic teratoma 11 to $20 \mathrm{~cm}$ and for mucinous cystadenoma 11 to $28 \mathrm{~cm}$. Pattern was similar to that seen in study done by Rather $\mathrm{G}$ et al. ${ }^{14}$

Malignant tumour were seen in 8 cases. All were surface epithelial tumours. Most common were the serous papillary cyst adenocarcinoma (5 cases). Simiar to study done by Sawant A et al. ${ }^{7}$ It was followed by 3 cases of mucinous cystadenocarcinoma. Size of these tumours ranged from 8 to $20 \mathrm{~cm}$. Borderline tumour were seen in 2 cases both were of Serous papillary borderline tumour. Gurung $\mathrm{P}$ et al ${ }^{15}$ in his study found 5 malignant cases and all were diagnosed as epithelial tumours on histology with serous cystadenocarcinoma being the most common as seen in our study.

Most common clinical presentation was abdominopelvic mass (60\%) followed by pain abdomen (22\%). This was similar to study done by Bodhal VK et al. ${ }^{16}$ Others were bleeding per vaginum $(10 \%)$, Incidental finding (6\%), rupture cyst with hemoperitoneum (2\%). Similar to study done by Neelgund $S$ et al. ${ }^{17}$
Conclusion-Ovarian cystic lesions are commonly encountered surgical specimens. Abdominopelvic mass is the predominant presentation. Histopathological examination is important to categorize them into neoplastic and non neoplastic lesion for proper treatment. Overall most of the cystic lesions of ovary are non neoplastic cysts. Follicular cyst being the most common cyst. Serous cystadenoma is the most common benign tumour presenting as cystic lesion. Among the malignant tumour serous cystadenocarcinoma was found to be the most common.

\section{Reference}

1. Ranabhat $\mathrm{S}$, Tiwari M, Maharajan $\mathrm{S}$ et al. Histopathologic spectrum of cystic ovarian masses. JCMC 2016;6(15):16-20.

2. Ellenson LH, Pirog EC. Robbins and Cotran pathologic basis of disease $9^{\text {th }}$ ed. Philadelphia (USA), Elsevier and Saunders Press; 2014. Chapter 22, The Female Genital Tract; p991-1042.

3. Kathikar SN, Dravid NV, Deore PN et al. Clinico histopathological Analysis of Neoplastic and Non neoplastic ovarian lesions: A 3 year prospective study in Dhule, North Maharashtra, India. J Clin Diagn Res.2014;8(8):4-7.

4. Bhuvanesh U, Logambai A. Study of ovarian tumours. J Obstet Gynaecol India. 1978;28:271-277.

5. Sheikh S, Bashir H, Farooq S et al. Histopathological spectrum of ovarian tumours from a referral hospital in Kasmir valley, Jammu and Kasmir, India. Intl J Res Med Sci.2017;5(5):2110-2114.

6. Dhakal R, Makaju R, Bastakoti R. Clinicomorphological Spectrum of Ovarian Cystic Lesions. Kathmandu Univ Med J 2016;53(1):13-16.

7. Sawant A, Mahajan S. Histopathological study of ovarian lesions at a tertiary health care institute. MVP J Med Sci 2017;4(1):26-29.

8. Murthy NS, Shalini S, Suman G et al. Changing trends in incidence of ovarian cancer-the Indian Scenerio. Asian Pac J Cancer Prev 2009;10(6):1025-1030.

9. Matinez Onsurbe P, Villaespesa AP, Anquela JMS. Aspiration cytology of 147 adnexal cysts with histologic correlation. Acta Cytol 2001;45:941-947.

10. 10.Kreuzer GF, Parodowski T, Wurche KD et al. Neoplastic or non neoplastic ovarian cyst The role of cytology. Acta Cytol 1995;39:882-886.

11. Gupta N, Bisht D, Agarwal AK et al. Retrospective and prospective study of ovarian tumours and tumour like lesions. Indian J Pathol Microbiol 2007;50(3):525-527.

12. Bukhari U, Memon Q, Memon H. Frequency and Pattern of ovarian tumours. Pak J Med Sci.2011;27:884-886.

13. Momtahen S, Kadivar M, Kazzazi AS et al. Gynaecologic malignancies in Tehran. Indian J of Cancer.2009;46:226230.

14. Rather GR, Gupta Y, Bhardwaj S. Pattern of lesions in hysterectomy specimens. J K Science 2013;15:63-68.

15. Gurung P, Hirachand S, Pradhanang S. Histopathological study of ovarian cystic lesions in a tertiary care hospital of Kathmandu, Nepal. J Institute of Medicine 2013;35(3):44-47.

16. Bodhal VK, Jindal, Bal MS et al. A ClinicoPathological study of Ovarian Lesions. RRJMHS 2014;3(1):50-56.

17. Neelgund S, Hiremath P. A retrospective study of ovarian cysts. Int J Reprod Contracept Obstet Gynecol.2016;5(6):1969-1973. 